\title{
CONSIDERATIONS ON THE JOINT RECOVERY OF THE MONUMENT AND ITS ENVIRONMENT: THE TOWN WALLS OF ALBARRACÍN (SPAIN)
}

\author{
J. L. Baró Zarzo ${ }^{1, *}$, J. Díaz Morlán ${ }^{2}$, F. J. Gómez-Patrocinio ${ }^{3}$ \\ ${ }^{1}$ Departamento de Composición Arquitectónica, Universitat Politècnica de València, Valencia, Spain - jobazar@cpa.upv.es \\ 2 Área de Urbanismo, Escuela de Ingeniería y Arquitectura, Universidad de Zaragoza, Zaragoza, Spain - 668673@unizar.es \\ ${ }^{3}$ I. U. de Restauración del Patrimonio, Universitat Politècnica de València, Valencia, Spain - fragmepa@upv.es
}

\section{Commission II - WG II/8}

KEY WORDS: Restoration, Heritage, Protective areas, Natural environment, Context linkage

\begin{abstract}
:
The city walls of Albarracín (Teruel) show an exemplary trajectory of restoration and conservation works, thanks to a fifty year-long trajectory of interventions carried out by different architects. The last of these projects, promoted by the City Council and driven by Fundación Santa María de Albarracin, was drafted in 2019 and involved the restoration of the southern end of the wall. For the first time, this project has addressed the recovery of the monument and its surroundings in a joint effort that bets on a global vision for the city's public space system. The keys to this binomial are based on the following premises: a well-coordinated monument-environment relationship, the emphasis on a conservative approach to the restoration works, the promotion of public use and the dignification of the space in a coherent way with its context. The joint treatment of the building and its environment goes far beyond an aesthetic or functional issue - which may have been achieved through independent projects - and verifies the criteria adopted for both dimensions of the project: minimal intervention, distinguishability, preservation of the authenticity, reversibility, compatibility, character, readability and sustainability. In general, this approach reduces the risks of unilateral, partial or limiting visions ending in the loss of heritage value and embraces the understanding of the immediate environment as an inseparable extension of the monument itself.
\end{abstract}

\section{CONTEXT OF THE INTERVENTION}

Albarracín (Teruel, Spain) is an Aragonese city with an outstanding medieval legacy that can still be perceived in its architecture and urban planning. It became a taifa ${ }^{l}$ and an independent estate during a period of the Middle Age, and its defensive necessities compelled it to a tight layout, with narrow streets and very few squares and open spaces (Almagro, 1993). Its typically reddish hamlet emerges from the top of a limestone crag carved out by the Guadalaviar river and surrounded by a defensive wall. Beyond the dwellings, the castle, the cathedral and the tower of Doña Blanca stand out as its most remarkable landmarks.

Five different factors must be considered to understand the importance of Albarracín within Spanish heritage preservation:

Landscape. Albarracín is a unique case of scenic integration, where a series of landforms (the meander where the city is settled, the surrounding hills, etc.) occupied by a rich variety of ecosystems (the pine forest of el Pinar de Rodeno, the poplar groves of the Guadalquivir meadow, the juniper forests, etc.) collude with the anthropogenic elements to create a perfect harmony. That can be observed in the adaptation of the urban scene to the topography, in the layout of the city's fortifications, in the materials and building techniques traditionally used or in the ancient subsistence economy (Figure 1).

Heritage. The remarkable built heritage of Albarracín is a consequence of its rich past, but cannot be separated from the territory that surrounds the city (Figure 2).

* Corresponding author

1 The taifas were the independent Muslim kingdoms of al-Andalus that emerged from the fall of the Umayyad Caliphate of Córdoba in the 11 th century.

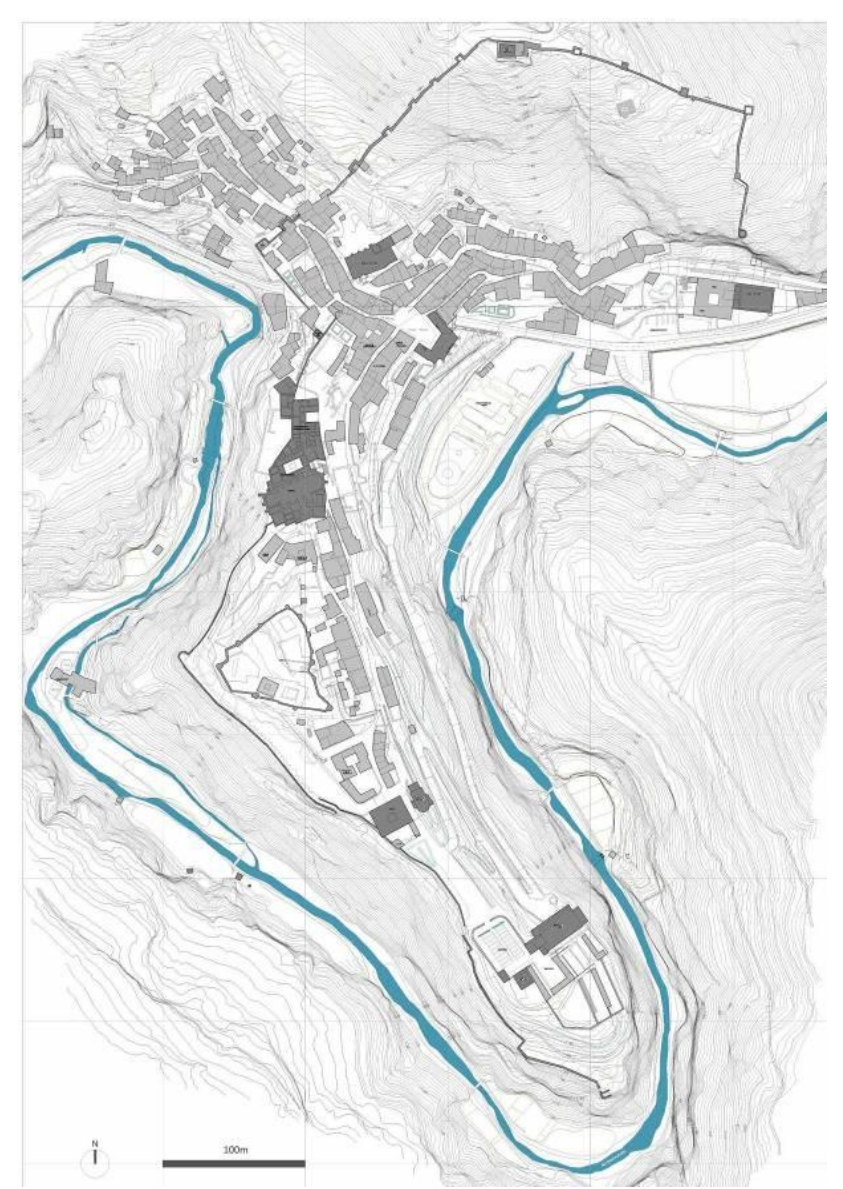

Figure 1. Plan of Albarracín (Díaz, 2014 from Almagro, 1993). 
Albarracín's built heritage is supported in high cultural values (historical, artistical of antiquity, etc.) that have made it worthy of different heritage designations, such as the designation of Conjunto Histórico de Albarracín ${ }^{2}$ in 1961, including the cathedral of El Salvador and the housing in the old town and historic suburbs, and Monumento Histórico-Artístico del Recinto Fortificado de Albarracin ${ }^{3}$ in 1931, including the castle and the city wall with its towers and gates.

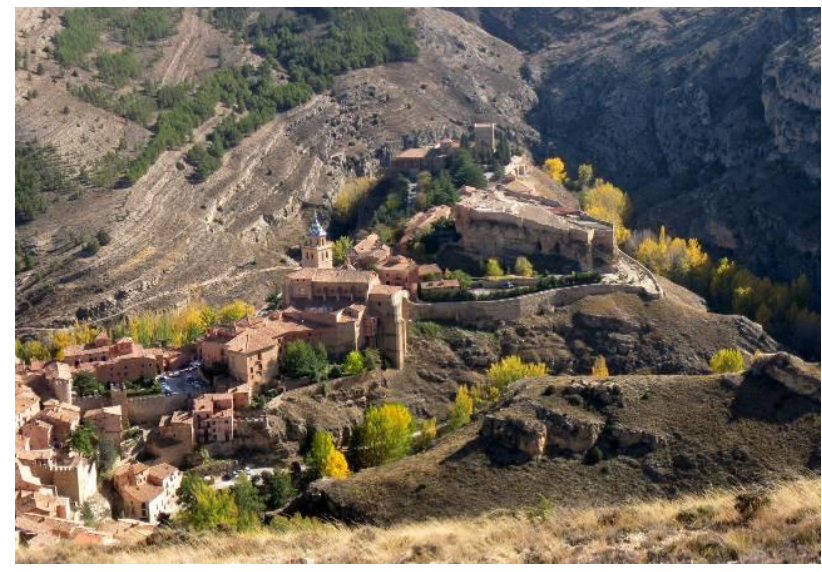

Figure 2. The city of Albarracín from the South (J. Díaz).

Urban management. The Plan Especial de Protección del Conjunto Histórico de Albarracín (1997), a document regulating the interventions allowed in the historic districts of the city, has played a leading role in the preservation of the urban layout and the appearance of vernacular buildings, promoting a delicate balance between the respect to tradition and necessity of adapting the city to modern living standards. This plan was a pioneer in including the surrounding natural landscape as a part of the protected area. This good example of heritage preservation driven by the urban management contrasts with the lack of a masterplan coordinating the interventions in the fortified precinct.

Heritage preservation. Albarracín is a national model regarding the restoration and management of architectural heritage. Despite some important transformations, the historic centre has endured historic vicissitudes (Spanish Civil War, depopulation processes, the evolution of necessities and lifestyle over the second half of the $20^{\text {th }}$ century, etc.) and preserves most of its original character. Its long trajectory in heritage preservation has led to some exemplary interventions, such as those carried out in the Cathedral, the church of Santa María or the Episcopal Palace, the latter awarded with the Europa Nostra Award in 1996. The efforts of the Fundación Santa María de Albarracin are largely responsible for the development of the city into a national and international referent in heritage preservation.

The restoration of the city walls has been carried out, stretch by stretch, over fifty years and nowadays only a minor section remains incomplete (Figure 3). As a result, the progressive evolution of preservation theories over this period can be easily observed in the comparison of the different interventions, ranging from strong restitutions to purely conservative works.

Heritage management. The management system - for both the local heritage and its preservation - has been mainly developed through an independent, non-profit entity that can be inhibited from political interference and mitigate the bureaucratic reluctance of official institutions: the Fundación Santa María de Albarracín. It is governed by a board composed by representatives of its founding institutions and by five members of a high cultural profile. The main goals of the foundation are the restoration, preservation and management of the local heritage and the revitalisation of its legacy.

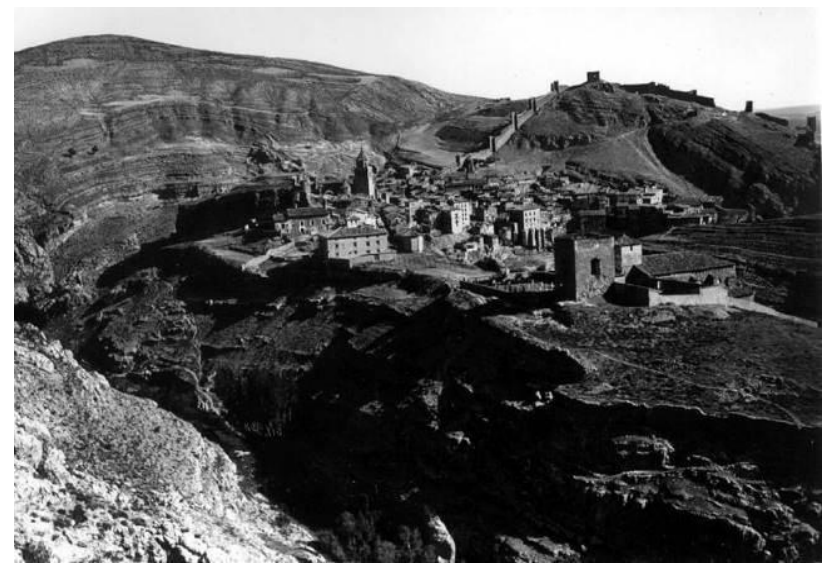

Figure 3. The city of Albarracín from the North (Instituto de Estudios Turolense, Archivo López Segura, 147, 25/6/1952).

\section{JOINT EXPERIENCE FROM A GLOBAL APPROACH}

Over the last decades, restoration initiatives have been mainly focused on the preservation of the built heritage, while the open spaces surrounding them have received a generic treatment. Consequently, the link between the monuments and their environment has usually been disregarded. For instance, the current design of the municipal park, set in an old orchard area by the meadow of the Guadalaviar river, shows a stiff, geometric pattern that includes imported species, foreign to the Albarracinian landscape. The rest of the city shows an erratic criterium that varies from artificial, eclectic interventions in the open spaces within the city centre to disorganised, sporadic interventions in the peri-urban spaces.

In 2019 , there is an inflexion point in the tutelary policy applied by some of the local agents, favourable to a change in the ongoing dynamics. The milestone that set this new way of treating the city and its heritage would be the decision of undertaking the preservation of a protected monument - a small section of the city wall - jointly with the natural regeneration of its surroundings.

Once again, the Fundación Santa María de Albarracin - in this case, through the City Council - is accountable for this new dynamic. The project, regarding the restoration of the southern section of the city wall and its surroundings, is currently approved by the heritage supervisors of the Aragonese government and on the lookout for funding. It has comprised the research work presented in this paper.

2 Declaración de Conjunto Histórico de Albarracín (Decree 1234/1961). Delimitación de BIC y entorno del Conjunto Histórico de Albarracin (Order 18 $8^{\text {th }}$ April 2011).

Declaración de Monumento Histórico-Artístico del Recinto Fortificado de Albarracín (Decree $3^{\text {rd }}$ June 1931). 


\subsection{The wall in the southern vertex of the historic city}

In the southern end of the historic city, behind the graveyard and the church of Santa María, the crag on which Albarracín is erected acquires an extremely steep orography, and the city wall disappears. Historically, this area was part of the Jewish quarter, while in the $17^{\text {th }}$ century - after the expulsion of Jews from Spain - it was allocated to the Dominican convent. After the confiscation of the ecclesiastical properties in 1835, the old convent was demolished, and the modern graveyard was built in its place. Over the $20^{\text {th }}$ century, consecutive extensions of the cemetery and continued dump of debris have led to a major decay of this area.

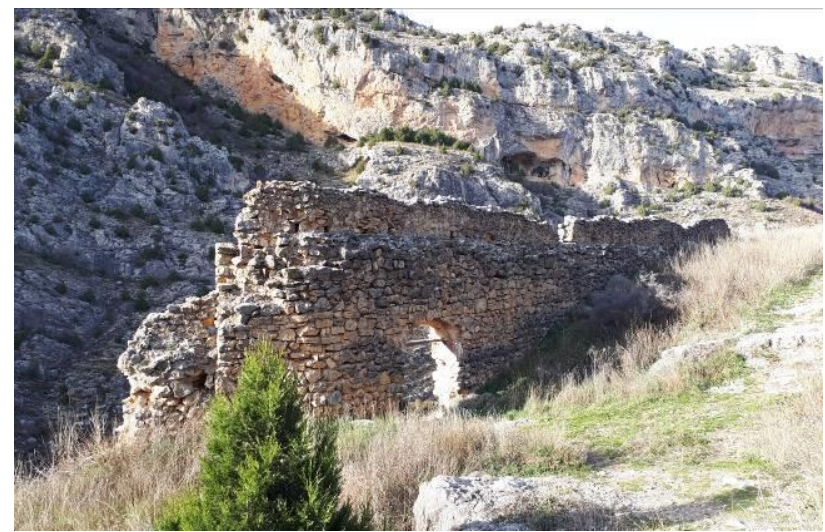

Figure 4. View of the wicket gate from the interior of the fortified precinct (J. Díaz).

The southern end of the wall shows a winding outline that is set at the edge of the rocky cliff. It shows no towers and, as it emerges directly from the rock, does not have foundations. The outer face of the wall does not slope and is crowned by a thinner parapet that leaves space for a narrow patrol path to the interior of the precinct. There have not been detected any traces of merlons, but some arrowslits can still be seen.
Some water drains conserved in the exterior of the wall show the original height of the ground in its inner face, which is now silted up to its crowning with debris. It has a wicket-gate opened in the path that descends towards the river (Figure 4) and the remaining of a structure that, according to Almagro (1987), may have been the watchtower that controlled this area until the construction of the tower of Doña Blanca.

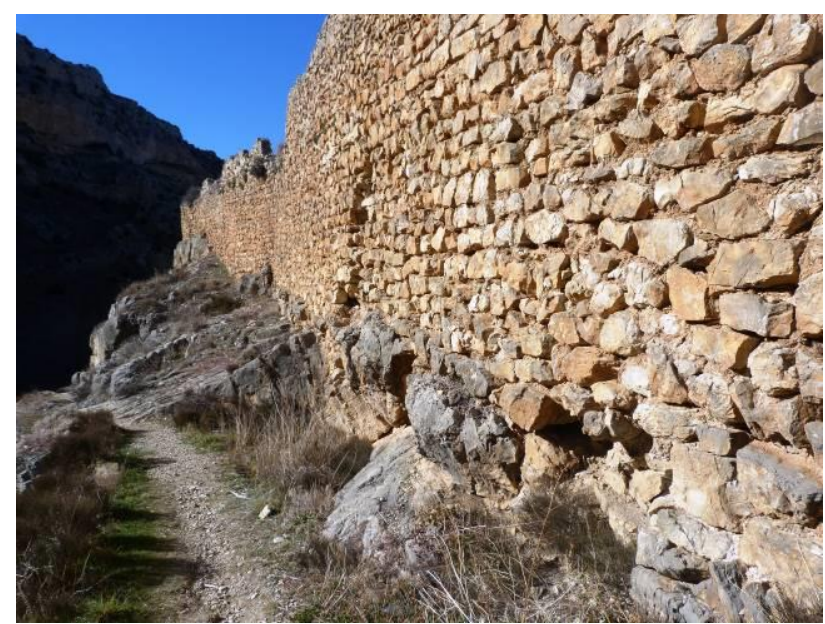

Figure 5. City wall of Albarracín, outer face of the Torre Blanca section (F. J. Gómez-Patrocinio).

All the stretches of the wall are formed by two external masonry layers, affixed using lime mortar, that confine a nucleus filled with lime concrete (Figure 5). Thick joints are due to the irregularity of the rough limestones, coming from the quarry known as Barranco de Rusia, that were used in the masonry walls. Only the protruding corner that starts the stretch with the wicket gate includes some coarsely carved ashlars.

This section of the wall, conserved in a surprisingly pristine state, shows some advanced decay processes that might lead to located instability if not treated.
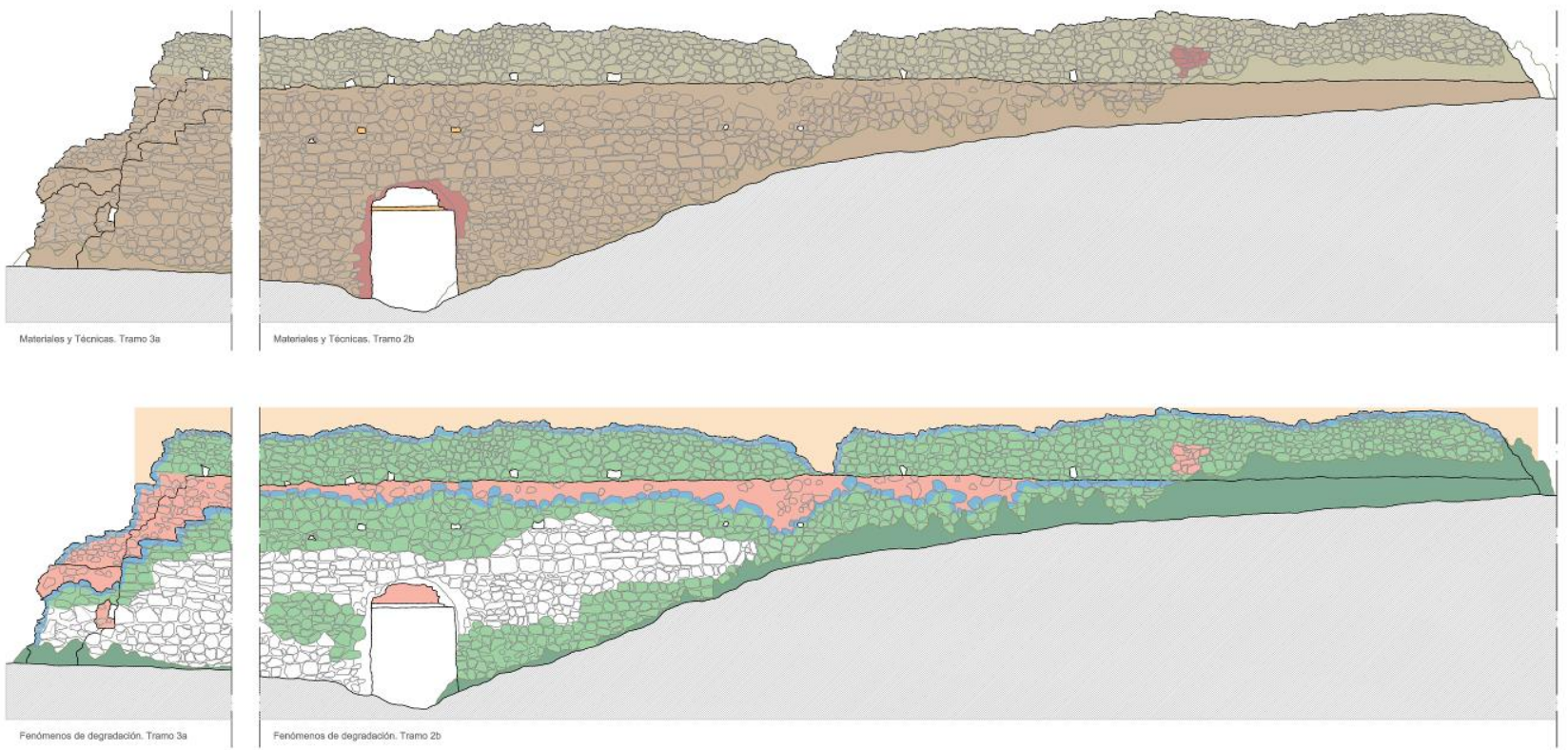

Figure 6. Study of the used constructive techniques and existing decay processes in the section of the wall containing the southern wicket-gate (Díaz and Baró, 2019). 


\subsection{Strategies for the intervention of the wall}

The preservation project outlined for this section of the wall takes in the strategies laid down in preceding interventions and develops them towards a strongly conservative approach. To achieve this, the project is based on criteria such as:

- Distinguishability

- Preservation of the authenticity

- Material compatibility

- Conservation of the character

- Durability

- Minimum intervention

- Environmental and economic sustainability

Decisions adopted can be grouped into three main strategies: structural consolidation of the wall, adaptation of the materials silting its inner face and improvement of the legibility of the monument (Figure 6).

First, the structural consolidation of the wall requires a specific treatment of each joint, attending to its degree of erosion and avoiding a homogeneous intervention. Some gaps in the masonry layers must also be stabilized to prevent further detachments. Three different ways of replenishment have been designed, according to different distinguishability needs.

The vast volume of debris accumulated in this area, which was the local landfill for over a century, made it impossible to address the recovery of the original ground level to the interior of the wall (Figure 7). Consequently, the project plans the substitution of the materials silting in the inner face of the wall by a draining filler relieved by the original gutters. However, the height of this filler will be lowered about a meter from its current level, which is even with the crowning of the wall.

This will recover some of the presence of the wall from the interior of the precinct, will reduce the thrust induced by the retained filler and will avoid the necessity of building a parapet or installing a guardrail to protect the edge of the cliff (Figure 8).
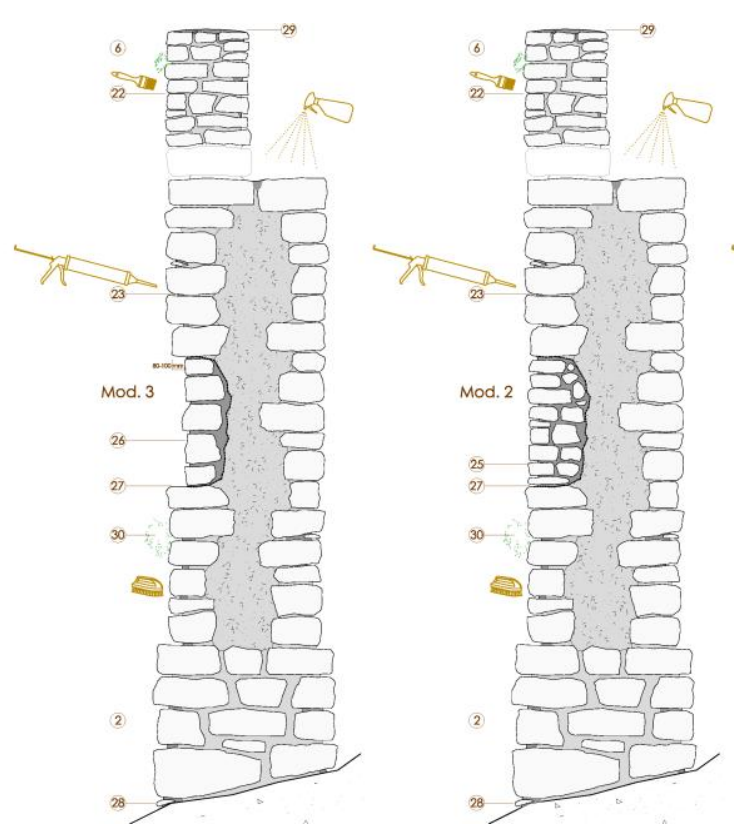

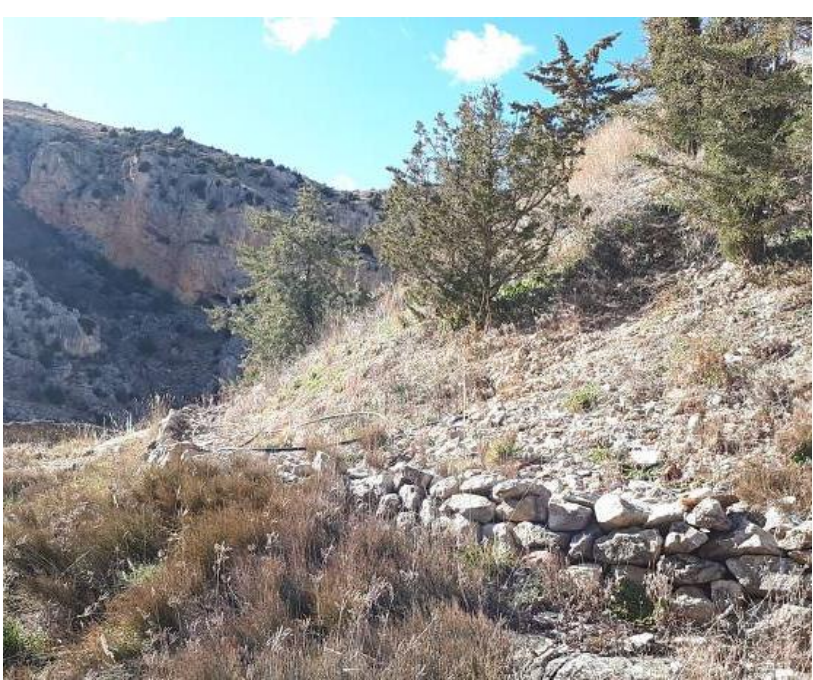

Figure 7. Historical debris dumped in the surroundings of the southern end of the city wall (J. Díaz).

Finally, the legibility of the monument will be improved with some located actions in selected points: the wicket gate, reintegrating its doorjambs; the parapet, protecting the areas where the original crowning has survived with a layer of lime mortar in the shape of a trunk; or the remaining of alleged southern watchtower, by increasing them to a height of $45 \mathrm{~cm}$. A previous archaeological survey will confirm all these actions

\subsection{Strategies for the landscape regeneration}

The strategies for the landscape regeneration have been based on a previous analysis that covered all the open spaces in Albarracín (Díaz, 2015) so that the intervention proposed would be set on a coherent, global vision of the city. In this way, the intervention area is regarded as a partially degraded section of the peri-urban area with a remarkable landscape value that, despite being within the city walls, must be linked to the naturalness of the mountains emerging at the other side of the Guadalaviar.

Figure 8. Detail of the project, showing the consolidation of the wall and the drainage of its inner face (Díaz and Baró, 2019). 


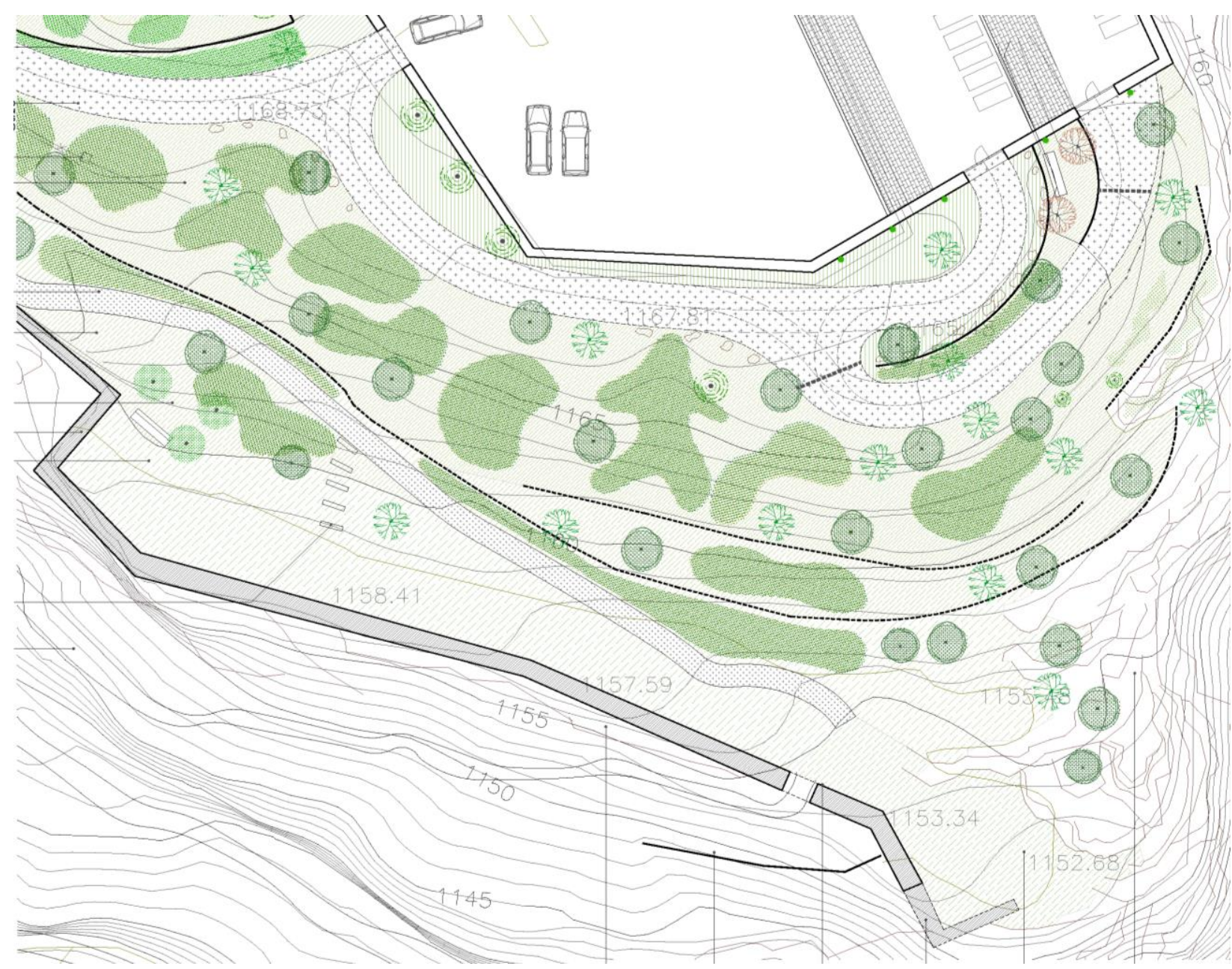

Figure 9. Plan of the projected landscape intervention (Díaz and Baró, 2019).

The joint vision of the open space system and the patrimonial dimension of Albarracín has provided the key elements of the planned intervention. The project proposes the re-naturalisation of the area by removing imported, distorting elements and substituting them with autochthonous species. It aims to revert the effects of some inappropriate interventions (relief alterations, species planted with inaccurate criteria, uncontrolled dumps, obsolete conductions, etc.) to dignify the environment of the monument and unify it with the lowly anthropized slopes that surround the city (Figure 9).

\subsection{Synergies}

The joint development of the project has led to a series of positive synergies that will improve both the design and intervention process.

The first element benefitted from these synergies is the historical path that descends towards the river from the terrace next to the graveyard. Its itinerary runs next to the wall at this area and, thanks to a coordinated design, will include small haven-viewpoint spaces that will improve the perception of the monument. Some metres further, the path crosses the wall through the wicket gate and leaves the fortified precinct. A lonely, tenuous uplight has been installed at this point, underlining its singularity as an inflexion point and turning it into a milestone in the landscape: from here on, the path abandons the city and plunges into nature (Figure 10).
The whole design process regarding the location of the haven spaces, the slopes, the position and design of the light, the materiality of the path, etc. has been enriched from those two different approaches to the project: landscape and heritage. Furthermore, the integrated development of the intervention works will result in better coordination of timing, movements, stockpiling, etc.

The use of dug earth during the preservation works exemplifies the benefits of this joint effort. The intervention in the inner face of the wall will require the excavation of a 3-metre-wide strip of ground, that will be substituted by a draining filler. To make the filler material, the dug-up ground will be sieved to remove smaller particles, leaving only the gravels that will enhance water filtration towards the gutters. These smaller particles will be necessary for the surroundings of the wall to recover the surface soil and allow naturalisation of the debris strata. This material transfer will save on loading, moving and dumping waste materials.

\section{CONCLUSIONS}

By way of conclusion, some reflections on this way of approaching heritage preservation can be extracted:

Joint intervention. As argued, a coordinated intervention in the monument and its surroundings strengthens its connection with its contexts and can reinforce the perception of its values. The main drawback of this approach might be an added complexity 
in the processes, as an increasing number of agents are involved. However, in the experience presented in this paper, no delays have been registered due to this cause.

Global vision. Transcending the specific point of view of each project would allow the implementation of transversal strategies of a bigger scale. The importance of this wider frame has been proved in this project, as a global analysis regarding the open spaces already existed (Díaz, 2015), but the city lacks a masterplan for the preservation of its walls.

Field of influence. Every patrimonial building is tightly linked to the place where they have been erected and are inevitably influenced by it. Consequently, the preservation of the surroundings is essential to preserve the building itself. In monumental complexes, such as Albarracín, the demarcation this area of influence is complex and must be set according to multiple factors (coherence of the ensemble, plurality of elements, connections among them, proportionality in the intervention, etc.).

Experience and context. How the public approaches a monument is a key factor in its perception and the mental and sensorial experience that it offers. As a result, it must be considered in protective interventions. The "discovery" factor influences the quality of the user's experience and directly influences its valuation. If an approaching path is important to this experience, its optimisation must be considered in the intervention.

Protective area. Joint interventions enable the implementation of global proposals and show the expedience of providing monuments with protective areas linked to them. This experience has shown the importance of this growing tendency in the set of laws regulating architectural heritage.

\section{REFERENCES}

Almagro Gorbea, A., 1987: El sistema defensivo de Albarracín. II Congreso de Arqueología Medieval Española, 2, 71-84. Dirección General de Patrimonio de la Comunidad de Madrid, Madrid.
Almagro Gorbea, A., 1993: Urbanismo y arquitectura en la Sierra de Albarracín. Instituto de Estudios Turolenses, Zaragoza.

Almagro Gorbea, A., Jiménez Martínez, A., Ponce de León, P., 2005: Albarracín. El proceso de restauración de su patrimonio artístico. Fundación Santa María de Albarracín, Zaragoza.

Baró Zarzo, J. L., De Haro Muñoz, M. Á., 2018: Construcción de nueva planta en entornos rurales protegidos: el caso de Albarracín (España). Loggia, Arquitectura \& Restauración, 31, $54-65$.

Betrán Abadía, R., 1992: La forma de la ciudad. Las ciudades de Aragón en la Edad Media. Colegio Oficial de Arquitectos de Aragón, Zaragoza.

Díaz Morlán, J., 2015: Análisis y propuesta de tratamiento de los espacios libres de la ciudad de Albarracín. XXIV Congreso de la Asociación de Geógrafos Españoles, De la Riva, J. et al (Eds.), p. 915-924. Universidad de Zaragoza - Asociación de Geógrafos Españoles, Zaragoza.

Díaz Morlán, J., Baró Zarzo, J. L., 2019. Restauración parcial de las murallas de Albarracín y adecuación paisajística de su entorno. Tramo Torre Blanca lienzo sur, continuación. Intervention project. Ayuntamiento de Albarracín.

González-Varas, I., 1999: Conservación de bienes culturales. Ed. Cátedra, Madrid.

Tomás Laguía, C., 1960: La geografía urbana de Albarracín. Teruel, 24, 5-128.

Vegas López-Manzanares, F., Mileto, C., 2014: Aprendiendo a restaurar: un manual de restauración de la arquitectura tradicional de la Comunidad Valenciana. Colegio Oficial de Arquitectos de la Comunidad Valenciana, Valencia.

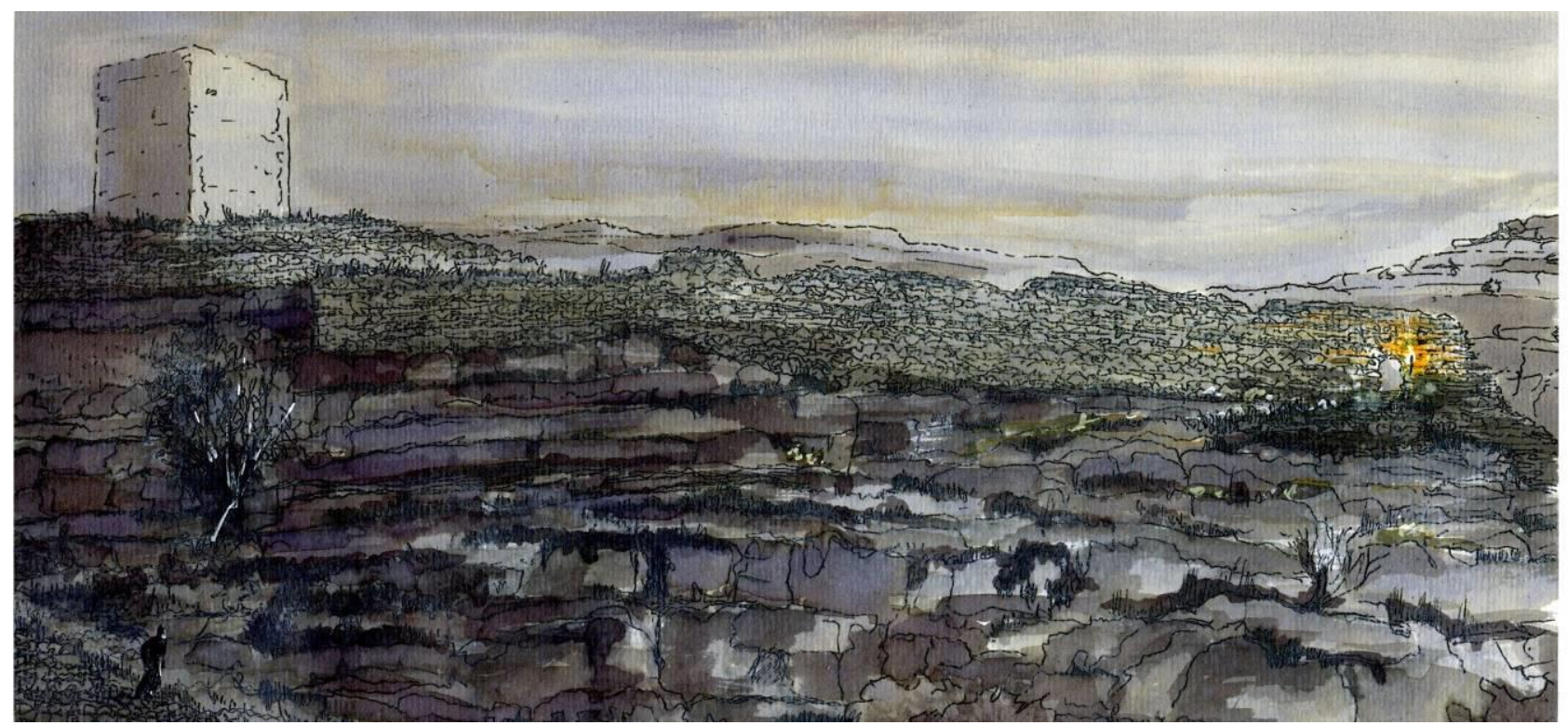

Figure 10. Sketch of the wall and its surroundings (J. Díaz). 